\title{
Identifikasi Miskonsepsi pada Materi Gaya Gesek
}

\author{
Arie Arma Arsyad*1, Dewi Sartika ${ }^{2}$ \\ 1,2 Universitas Sulawesi Barat; \\ e-mail: *1ariearmaarsyad200389@gmail.com \\ ${ }^{* 2}$ dewisartika.asrulbaturan@gmail.com
}

\begin{abstract}
Abstrak
Salah satu yang menjadikan fisika sulit bgi siswa adalah adanya miskonsepsi. Miskonsepsi terjadi akibat ketidaksamaan antara konsep yang dimiliki siswa dengan konsep sebenarnya. Penelitian ini bertujuan untuk mengidentifikasi miskonsepsi-miskonsepsi yang ada pada materi gaya gesek sehingga konsep yang salah dapat diremediasi. Penelitian ini adalah jenis penelitian deskripif di mana pengumpulan data dengan melakukan tes diagnostik. Hasil tes diagnostic yang dilakukan menunjukkna adanya beberapa miskonsepsi pada materi gaya gesek, di anataranya berkaitan dengan gaya-gaya yang bekerja pada benda yang diam dan bergerak. Pada konsep-konsep ini persentase kesalahan siswa dalam menjawab soal-soal tes cenderung tinggi.
\end{abstract}

Kata kunci: miskonsepsi, gaya gesek.

\section{PENDAHULUAN}

Ibrahim (2012) menyatakan bahwa miskonsepsi adalah pandangan yang berbeda dengan pandangan ahli yang sudah disepakati dan dianggap benar. Salah satu kesulitan yang dialami siswa dalam belajar fisika adalah karena adanya miskonsepsi (Van den berg, 1991). Sebelum guru memberikan materi, siswa sudah memiliki pemahaman tersendiri dalam melihat suatu permasalahan, hal ini yang disebut dengan prakonsepsi. Prakonsepsi yang salah akan hilang saat guru memberikan konsep yang benar (Ibrahim, 2012). Apabila orang tersebut memiliki konsep yang selalu kembali ke prakonsepsinya meskipun sudah dikenalkan konsep yang sebenarnya maka orang tersebut mengalami miskonsepsi. Hal yang perlu dicatat adalah bukan berarti bahwa guru ataupun dosen bebas dari miskonsepsi. Van den berg (1991) menyatakan bahwa kadang penalaran guru ataupun dosen fisika terganggu oleh intuisi yang salah. Masalah yang ditimbulkan akan menjadi lebih kompleks jika guru ataupun dosen fisika tidak bebas dari miskonsepsi.

Miskonsepsi sendiri bisa bersumber dari diri siswa (Ibrahim, 2012). Miskonsepsi pada siswa yang muncul secara terus menerus dapat mengganggu pembentukan konsepsi ilmiah. Pembelajaran yang tidak memperhatikan miskonsepsi menyebabkan kesulitan belajar dan akhirnya akan menghasilkan pada rendahnya prestasi belajar mereka. Miskonsepsi yang bersifat resisten dikarenakan setiap orang membangun pengetahuan sesuai dengan pengalamannya. Sekali kita telah membangun pengetahuan, maka tidak mudah untuk memberi penjelasan bahwa hal tersebut salah hanya dengan melalui memberi informasi untuk mengubah miskonsepsi itu. 
JURNAL SAINTIFIK VOL.2 NO.2, JULI 2016

Jadi cara untuk mengubah miskonsepsi adalah dengan jalan mengkonstruksi konsep baru yang lebih cocok untuk menjelaskan pengalaman.

Sejumlah miskonsepsi sangatlah bersifat resistan, walaupun telah diusahakan untuk menyangkalnya dengan penalaran yang logis dengan menunjukkan perbedaannya dengan pengamatan-pengamatan sebenarnya, yang diperoleh dari peragaan dan percobaan yang dirancang khusus untuk maksud itu. Oleh karena itu, penting bagi para pendidik untuk menemukan miskonsepsi pada siswa sehingga dapat dilakukan langkah-langkah untuk melakukan remidiasi miskonsepsi tersebut. Beberapa cara remidiasi diusulkan oleh Van den Berg (1991) antara lain dengan cara menyesuaikan pembelajaran sesuai dengan cara berfikir siswa, menggunakan konflik kognitif, analogi, interaksi pasangan, metalearning, dan demonstrasi.

Metode untuk menemukan miskonsepsi pada siswa adalah dengan menggunakan tes diagnostik. Tes diagnostik adalah tes yang digunakan untuk mengetahui kelemahan-kelemahan siswa sehingga hasil tersebut dapat digunakan sebagai dasar untuk memberikan tindak lanjut berupa perlakuan yang tepat sesuai dengan kelemahan yang dimiliki oleh siswa (Depdiknas, 2007).

Tes diagnostik memiliki dua fungsi utama, yaitu untuk mengidentifikasi masalah atau kesulitan yang dialami siswa dan untuk merencanakan tindak lanjut berupa upaya-upaya pemecahan sesuai masalah atau kesulitan yang telah teridentifikasi (Depdiknas, 2007). Dari kedua fungsi tersebut menunjukkan bahwa tes diagnostik dapat digunakan untuk mengidentifikasi miskonsepsi yang ada pada siswa.

Konsep yang akan diuji adalah konsep mengenai materi gaya gesek. Materi ini disampikan di kelas XI. Melalui pengidentifikasian ini nantinya diharapkan dapat memberikan solusi bagi remediasi miskonsepsi-miskonsepsi yang ditemukan, khusunya remediasi dalam materi gaya gesek.

\section{METODE PENELITIAN}

Jenis penelitian yang dilakukan adalah penelitian deskriptif yang bertujuan untuk mengumpulkan informasi tentang pemahaman konsep siswa pada materi gaya gesek. Subyek pada penelitian ini adalah siswa SMA Negeri Makasar yang telah memperoleh pelajaran tentang gaya gesek. Instrument yang digunakan adalah tes diagnostik yang digunakan untuk mengidentifikasi pemahaman siwa terhadap konsep yang doteliti.

Secara garis besar penelitian dibagi menjadi tiga tahap, yaitu tahap persiapan, tahap pelaksanaan, dan tahap analisis data untuk identifikasi miskonsepsi sisa. Adapun tahap-tahap tersebut dijelaskan sebagai berikut:

1. Tahap pertama adalah tahap persiapan. Dalam tahap ini dilakukan analisis materi yang mungkin memberikan peluang terjadinya miskonsepsi pada siswa, pembuatan kisi-kisi soal tes diagnosis yang bertujuan untuk menguji pemahaman konsep tentang cahaya, dan konsultasi kisi-kisi tersebut dengan pakar.

2. Tahap kedua adalah tahap pelaksanaan. Pada tahap ini dilaksanakan tes diagnostik untuk mengidentifikasi miskonsepsi pada siswa SMP Pancasila Palangka Raya. Soal diagnostik yang dikembangkan berupa soal pilihan ganda yang disertai alasan sesuai dengan konsepsinya. 
3. Tahap ketiga merupakan tahap analisis data. Data yang didapatkan kemudian ditabulasikan untuk dan dihitung persentase masing-masing kesalahan dan miskonsepsi. Hasil analisis data ini dijadikan dasar penarikan kesimpulan yang berkaitan dengan miskonsepsi pada materi cahaya.

\section{HASIL DAN PEMBAHASAN}

\section{Hasil Penelitian}

Tes diagnostik dilaksanakan pada siswa SMA Negeri Makassar. Adapun hasil tes disajikan pada Tabel 1 berikut ini.

Tabel 1. Hasil Tes Diagnostik

\begin{tabular}{|c|c|c|c|c|c|c|c|c|c|c|c|c|c|c|c|}
\hline \multirow{3}{*}{ No. } & \multicolumn{15}{|c|}{ Nomor Soal } \\
\hline & \multicolumn{2}{|c|}{1} & \multicolumn{2}{|c|}{2} & \multicolumn{3}{|c|}{3} & \multicolumn{2}{|c|}{4} & \multirow{2}{*}{5} & \multirow{2}{*}{6} & \multirow{2}{*}{7} & \multicolumn{3}{|c|}{8} \\
\hline & $\mathrm{a}$ & $\mathrm{b}$ & $\mathrm{a}$ & $\mathrm{b}$ & $\mathrm{a}$ & $\mathrm{b}$ & $\mathrm{c}$ & $\mathrm{a}$ & $\mathrm{b}$ & & & & $\mathrm{a}$ & $\mathrm{b}$ & $\mathrm{c}$ \\
\hline$\Sigma$ & 25 & 16 & 6 & 3 & 4 & 5 & 1 & 20 & 1 & 0 & 0 & 0 & 3 & 5 & 4 \\
\hline$\%$ BENAR & 100 & 64 & 24 & 12 & 16 & 20 & 4 & 80 & 4 & 0 & 0 & 0 & 12 & 20 & 16 \\
\hline$\% \mathrm{SALAH}$ & 0 & 36 & 76 & 88 & 84 & 80 & 96 & 20 & 96 & 100 & 100 & 100 & 88 & 80 & 84 \\
\hline
\end{tabular}

\section{Pembahasan}

Hasil tes diagnostik di atas menggambarkan bahwa pada soal nomor 1, siswa menghubungkan kaitannya antara gaya-gaya yang bekerja pada benda dengan hokum I Newton. Untuk soal nomor 2, kebanyakan siswa menjawab bahwa besar gaya gesek lebih besar dibandingkan dengan gaya tarik pada benda. Hal ini dipengaruhi oleh schemata yang dimiliki oleh siswa sebelumnya bahwa jika ada gaya tarik yang bekerja pada sebuah benda kemudian benda itu tidak bergerak maka gaya gesek yang timbul lebih besar dibandingkan dengan gaya tariknya. Untuk soal nomor 3 dan 4, kebanyakan siswa mengatakan bahwa besar gaya gesek lebih kecil dibandingkan dengan besar gaya tarikan yang kemudian mereka mengambil kesimpulan bahwa besar resultan gaya pada benda itu lebih besar dari nol. Hal ini dipengaruhi oleh schemata yang dimiliki oleh siswa bahwa beenda yang bergerak mempunyai gaya luar yang lebih besar dibandingkan gaya gesek yang menyebabkan resultan gayanya tidak sama dengan nol jika bergerak dengan kecepatan konstan yang sesuai dengan arah percepatan yang dimiliki oleh suatu benda akan sama dengan arah resultannya. Untuk soal nomor 5, 6, 7, dan 8 adalah soal penerapan mengenai kaitan soal-soal sebelumnya dengan persamaan yang digunakan. Sebagian besar siswa menggunakan persamaan yang mereka ketahui untuk mengatasi permasalahan ini. Hal ini dipengaruhi karena siswa lebih cenderung menggunakan persamaan dibandingkan dengan logika sederhana yang sebetulnya dapat diselesaikan.

Mengatasi miskonsepsi fisika siswa ternyata bukan persoalan yang mudah karena sejumlah miskonsepsi fisika bersifat resistan meskipun telah diusahakan untuk menjelaskannya dengan penalaran logis melalui penunjukan perbedaannya dengan pengamatan sebenarnya yang diperoleh dari peragaan dan percobaan. Penyebab dari ressitannya sebuah miskonsepsi karena setiap orang membentuk pengetahuan dalam kepalanya persis dengan pengalaman yang diperolehnya. Begitu pengetahuan terbentum dalam diri siswa dari pengalaman yang diperoleh 
JURNAL SAINTIFIK VOL.2 NO.2, JULI 2016

secara langsung maka akan menjadi susah untuk member tahu siswa itu untuk mengubah miskonsepsi itu (Wiliantara, 2005). Salah satu cara yang penulis anggap tepat dalam remediasi miskonsepsi gaya gesek adalah dengan memunculkan konflik kognitif melalui metode demonstrasi.

Dari hasil tes diagnostik di atas dapat diketahui bahwa schemata yang terbentuk pada siswa menjadi hambatan proaktif dalam meahami gaya gesek. Untuk mengatasi hal ini, maka penulis memilih metode ceramah dengan eksperimen sebagai sebuah solusi dalam meminimalisir terjadinya hambatan proaktif maupun miskonsepsi. Seperti halnya teori ilmuwan dalam fisika, "teori siswa" juga dapat diuji. Misalnya siswa dihadapkan dengan permasalahan seperti pada soal di atas, kemudian merekan disuruh untuk meramalkan apa yang akan terjadi. Setelah siswa mengemukakan jawaban dan pendapat masing-masing, mereka dituntun untuk melakukan percobaan seperti pada soal di atas. Jika hasil percobaan siswa tidak cocok dengan ramalan mereka sebelumnya, maka tentu saja siswa menghadapi konflik kognitif yang dapat menghasilkan perubahan jaringan konsep dalam otak siswa (perubahan struktur kognitifnya). Perubahan itu belum tentu benar. Disinilah peran seorang guru yang akan menjadi fasilitator dan mediator yang akan menjembatani kesenjangan atara schemata yang telah terbentuk di otak siswa dengan materi gaya gesek dan fakta-fakta dalam hasil demonstrasi.

\section{KESIMPULAN}

Dari hasil obsevasi yang dilakukan penulis dapat disimpulkan bahwa:

1. Penyebab terjadinya miskonsepsi pada gaya gesek disebabkan oleh schemata yang sudah terbentuk sebelumnya.

2. Kurangnya demonstrasi tentang gaya gesek dapat menjadi penghambat dalam meluruskan miskonsepsi terhadap gaya tersebut.

3. Siswa masih terkendala dalam melihat banyaknya gaya yang bekerja pada sebuah benda.

4. Metode ceramah yang dikaitkan dengan metode eksperimen merupakan salah satu solusi yang dapat digunakan untuk mengajarkan gaya gesek dan menjadikan jembatan antara schemata awal yang sudah terbentu agar tidak terjadi hambatan proaktif.

\section{DAFTAR PUSTAKA}

Euwe van den berg. 1990. Miskonsepsi Fisika dan Remediasi. Salatiga: Universitas Kristen Satya Wacana

Handayani,Sri dkk. 2009. Fisika Untuk SMA dan MA Kelas X. Jakarta: Pusat Perbukuan Departemen Pendidikan Nasional.

Hewitt, Paul G. 2002. Practicing Physic: Conceptual Physics $9^{\text {th }}$ Edition. San Fransisco: City College of San Fransisco.

Prasetio, Lea. 1992. Mengerti fisika: Mekanika. Yogyakarta: Andi Offset Yogyakarta. 